\title{
保険・共済実務における個人情報漏洩 防止の近時の動向
}

武田俊裕

\section{ロアブストラクト}

保険・共済事業に関する個人情報の保護については，個人情報の保護に関 する法律および金融庁等のガイドラインを中心とした規制が行われ，その下 で，各事業者は組織的・人的・技術的な各種の安全管理措置を部門横断的に 講じ，個人情報をめぐる様々な環境の変化に対応している。実務における近 時の動向として, 反社会的勢力との取引の排除に向けて従来よりも多くの個 人情報の蓄積・管理・活用がすすめられており，機微情報（犯罪歴）が含ま れていることから慎重な取扱いが求められている点と, 平成26年に発生した 個人情報の大規模漏洩事件を契機として，内部不正による漏洩を防ぐための 対策の充実が求められている点が挙げられる。これらと並行して, 多くの部 門・拠点において大量の個人情報を取り扱うという事業特性を踏まえ, 実際 に生じている事故の原因・背景に応じて実効性のある未然防止・再発防止策 を講じていく不断の取組みも不可欠である。

\section{ロキーワード}

個人情報保護, 反社会的勢力, 金融庁ガイドライン

\section{1 はじめに}

保険事業者の取り扱う個人情報については，保険契約・事業運営の性格上， *平成27年 3 月 6 日の日本保険学会関東部会報告による。

/平成28年 4 月 1 日原稿受領。 
保険・共済実務における個人情報漏洩防止の近時の動向

次のような特徵があり，その取得・管理・利用・提供にあたつて，より高度 な保護が求められる ${ }^{1)}$ 。

ア．多くの契約を締結することにより，大量の情報を取り扱うこと

イ、長期にわたる契約に関しては, 情報の管理も長期化し, 契約内容の変 更等により多様で複雑な管理が生じ得ること

ウ. 保険契約者・被保険者・保険金受取人以外に，事故の加害者・被害者， 医療機関，債権者，相続人，保険料納入・保険金支払に関わる金融機関， 他の保険会社等多くの関係者が存在すること

工。引受審査や保険給付にあたり, 健康状態・病歴, 収入, 所有する財産 の価額, 事故歴, 請求履歴, 反社会的勢力該当性等, 機微性の高い情報 を取り扱うこと

才。募集・保全にかかる過程において, 代理店・募集人が介在すること

こうした特徵があることから，いったん個人情報の漏洩またはそのおそれ のある事故（以下「漏洩等」という。）が生じると, 漏洩先からの書類の回 収，書類紛失の場合の関係拠点での捜索，本人への通知・謝罪，原因の特定， 行政庁への報告等に相応のコストを要することとなり，仮に損害賠償をめぐ る紛争に発展すれば, さらに大きな負担となるおそれがある。また，漏洩等 の規模・内容によっては，業務改善命令等の行政処分が行われることに加え， それが広く報道され，事業者に対する社会的信頼を大きく損なう結果を招く ことも想定される。

上述の特徴やリスクは共済事業を実施する団体においても全く同様であり， 保険・共済事業者は，個人情報の保護に関する法的・行政的規制の下，各種 の安全管理措置を講じ, 漏洩等の未然防止・再発防止に取り組んでいるとこ ろである。

1）勝野義孝「個人情報保護法の除外事由の趣旨とその限界」保険学雑誌第587 号111頁 (2004)。 


\section{2 個人情報保護にかかる規制の概要}

\section{（1） 個人情報保護法}

わが国における個人情報保護法制は，「個人情報の保護に関する法律」（平 成 15 年 5 月 30 日法律第57号）（以下「個人情報保護法」という。）において 「個人情報の適正な取扱いに関し，基本理念及び政府による基本方針の作成 その他の個人情報の保護に関する施策の基本となる事項を定め, 国及び地方 公共団体の責務等を明らかにするとともに，個人情報を取り扱う事業者の遵 守すべき義務等を定め」（第 1 条），その下に，公的部門・民間部門ごとに次 のような規範が置かれるという形をとっている。

ア．公的部門については，国の行政機関を対象とした「行政機関の保有す る個人情報の保護に関する法律」, 独立行政法人等を対象とした「独立 行政法人等の保有する個人情報の保護に関する法律」, 各地方公共団体 において制定される個人情報保護条例が，それぞれ設けられている。

イ、民間部門については，事業分野ごとに所管の省庁が告示や通達の形で ガイドラインを制定している。保険会社に対しては，金融庁が「金融分 野における個人情報保護に関するガイドライン」(平成 16 年 12 月 6 日告 示）を設けており，各種の協同組合法に基づてて実施される共済事業に 対しては，農業協同組合法・水産業協同組合法に基づいて行われるもの について農林水産省が「農林水産分野における個人情報保護に関するガ イドライン」(平成21年 7 月 10 日告示 ${ }^{2)}$ ) を, 中小企業等協同組合法に 基づいて行われるものについて経済産業省が「個人情報の保護に関する 法律についての経済産業分野を対象とするガイドライン」(平成16年10 月22日告示）を，それぞれ設けている ${ }^{3)}$

2）この告示に伴い，農林水産省は，平成16年11月 9 日付の旧ガイドラインを廃 止している。

3）消費生活協同組合法に基ついて実施される共済事業に関しては, 厚生労働省 はガイドラインを設けていないが，日本生活協同組合連合会が自主的に制定し た「生協における個人情報保護ガイドライン」および後掲注7）の「共済事業 
保険・共済実務における個人情報漏洩防止の近時の動向

(1) 個人情報保護法の主な内容

個人情報保護法は，民間部門において個人情報データベース等（第 2 条第 2 項）を事業の用に供している者を「個人情報取扱事業者」と定義し（第 2 条第 3 項），第 4 章第 1 節において，利用目的の特定と遵守（第 $15 \cdot 16$ 条）, 適正な取得と取得時の利用目的の公表・通知 (第17・18条), データ内容の 正確性の確保（第19条），安全管理措置と従業者・委託先の監督（第20２2 条), 第三者への提供の制限 (第23条), 保有個人データ（第 2 条第 5 項）に かかる利用目的等の公表・通知（第24条，第28～30条），本人の請求による 開示・訂正 ·追加 · 削除・利用停止 (第25～30条), 苦情処理（第31条）を 個人情報取扱事業者に義務付けるとともに，主務大臣による報告徴収・助 言・钦告・命令（第32～36条）に関する規定を設けている。

\section{(2) ガイドラインの主な内容}

上記のように，各省庁は，所管する事業分野における「個人情報の性質及 び利用方法にかんがみ, 事業者が講ずべき措置の適切かつ有効な実施を眓る ための指針」としとてガイドラインを設けている。金融庁は，保険業を含む 金融分野における個人情報保護に関するガイドラインにおいて，機微情報の 取扱い（第 6 条），安全管理措置の内容（第10条），漏洩事案等への対応（第 22 条), 個人情報保護宣言の策定・公表および望ましい内容 (第23条), 勧 告・命令にかかる判断基準 ·手続（第24条）等, 個人情報保護法の各条項の 解釈・運用方針を明文化している ${ }^{5)}$ 。

における個人情報保護のための取扱指針等について」を踏まえて各組合が自主 的に取り組むこととされている（平成16年12月17日厚生労働省社会・援護局地 域福祉課長通知)。

4）金融分野における個人情報保護に関するガイドライン第 1 条第 1 項。

5）個人情報保護法が施行された際，同法第 8 条において国が「事業者等が講ず べき措置の適切かつ有効な実施を図るための指針の策定」を行う旨定められた ことに対応して各省庁がガイドラインを設けていたが, 平成20年 7 月に開催さ れた個人情報保護関係省庁連絡会議において, 各事業分野のガイドラインの共 
このうち機微情報については,「政治的見解，信教（宗教，思想及び信条 をいう。), 労働組合への加盟, 人種及び民族, 門地及び本籍地, 保健医療及 び性生活，並びに犯罪歴に関する情報」をいう旨定めたうえ，事業者が取得， 利用および第三者提供を行い得る場合を限定している。保険・共済の実務に おいて問題となることが多いのは保健医療および犯罪歴に関する情報である が，これらについて金融庁は「顧客が成年後見制度における被後見人である という情報は, 保健医療の内容を特定するものでないため, 機微情報に該当 しない」,「新聞に掲載された犯罪歴等公表された情報は，機微情報に該当し ない」といった解釈を明らかにしている ${ }^{6)}$ 。

また，安全管理措置に関しては，事業者に対して，「基本方針・取扱規程 等の整備及び……実施体制の整備等の必要かつ適切な措置」を求めるととも に，その措置には「組織的安全管理措置」「人的安全管理措置」および「技 術的安全管理措置」を含むべきことを定め（第10条第 1 項），それぞれにつ いて講ずべき具体的な措置を列挙している(同条第 $5 \cdot 6$ 項 $)^{7)}$ 。その内容

通化に取り組むことについて申合せがなされたことを踏まえ，各省庁のガイド ラインが改正され，現行規定の基礎となっている。

6) 浅井弘章 - 個人情報保護法と金融実務第 3 版57頁（金融財政事情研究会, 2006), 小森純子 $=$ 小西賢治・金融分野における個人情報の保護一金融庁ガイ ドラインおよび安全管理措置の解説48頁（金融財政事情研究会, 2006)。

7）金融庁は，ガイドラインに定めた安全管理措置にかかるさらに詳細な指針と して「金融分野における個人情報保護に関するガイドラインの安全管理措置等 についての実務指針」を定めている。生命保険協会および日本損害保険協会は, 金融庁の定めたガイドラインとこの実務指針を踏まえ，個人情報保護法第37条 に基づく「認定個人情報保護団体」として，次の指針を設けている。

・「生命保険業に扔ける個人情報保護のための取扱指針」（生命保険協会）

・「生命保険業における個人情報保護のための安全管理措置等についての実務 指針」(生命保険協会)

・「損害保険会社に扔ける個人情報保護指針」（日本損害保険協会）

・「損害保険会社における個人情報保護指針に関する安全管理措置等について の実務指針」(日本損害保䧍協会)

また，各種の協同組合法に基づいて共済事業を実施する団体に関しては，日 本共済協会が,「共済事業における個人情報保護のための取扱指針等について」 
保険・共済実務に㧍ける個人情報漏洩防止の近時の動向

は広範なものであり, 事業者においては, 諸規程の制定・改廃, 役員の関与, 監査，各部門の責任者の配置といった内部統制に関わる部門をはじめとして， 法務およびコンプライアンスに関わる部門，文書管理・契約事務手続の策定 に関わる部門，情報システムに関わる部門，職員との個人データ非開示契約 や職員への教育・研修に関わる部門，苦情対応に関わる部門，漏洩等が生じ た場合の広報・行政庁対応に関わる部門等が，個人情報保護に関する知識・ 問題意識を共有し, 機動的に連携しながら管理態勢の充実と漏洩等の防止に 取り組むことが求められている。

\section{(2) 保険業法施行規則等}

保険業法施行規則は, 個人情報の保護に関して次のような規定を設け，保 険会社を規制している。

ア，個人である顧客に関する情報の安全管理，従業者の監督および当該情 報の取扱いの委託先の監督について, 当該情報の漏洩・滅失・毀損の防 止を眓るために必要かつ適切な措置を講じることを保険会社に義務付け る（第53条の 8）とともに，生命保険募集人，損害保険代理店，少額短 期保険募集人または保険仲立人が，この措置を怠ることを，保険業法第 300 条第 1 項第 9 号に定める行為として禁止している（第234条第 1 項第 16号)。

イ、個人である顧客に関する人種, 信条, 門地, 本籍地, 保健医療または 犯罪経歴についての情報その他の特別の非公開情報 ${ }^{8)}$ を, 必要と認めら れる目的以外の目的のために利用しないことを確保するための措置を講 じることを保険会社に義務付ける（第53条の10）とともに，この措置を 吝ることを, 保険業法第300条第 1 項第 9 号に定める行為として禁止し

を設けている。

8）「その他の特別の非公開情報」の具体的内容について, 金融庁は「保険会社 向けの総合的な監督指針」において, 労働組合への加盟, 民族および性生活に 関する情報をいう旨定めている（II-4-5-2(2)(2)）。 
ている（第234条第 1 項第17号）。

同旨の規制は，各種の協同組合法に基づいて共済事業を実施する団体に対 しても設けられている ${ }^{9)}$ 。

\section{（3）監督指針}

金融庁は,「保険会社向けの総合的な監督指針」の「II - 4 - 5 顧客等 に関する情報管理態勢」において，「個人である顧客に関する情報について は，規則，個人情報の保護に関する法律，保護法ガイドライン及び実務指針 の規定に基づく適切な取扱いが確保される必要がある」としたうえで，情報 管理態勢に関して, 経営陣の関与, 情報の取扱基準の制定と役職員への周知 徹底，アクセス・持出しの管理と不正アクセス防止，外部委託先にかかる措 置，漏洩発生時の対応，内部監査にかかる着眼点を定めるとともに，個人情 報の管理に関して保険業法施行規則やガイドラインに則した措置が講じられ ているかを着眼点として定め，問題がある場合には保険業法に基づく報告徴 収・命令等により対応する ${ }^{10)}$ 旨定めている。同様に, 各種の協同組合法に基

9）農業協同組合法施行規則第 22 条第 11 号・第 12 号，第30条の 2 ，第30条の 4 , 水産業協同組合法施行規則第 21 条第 11 号・第 12 号，第54条，第56条，消費生活 協同組合法施行規則第 18 条第 1 項第 15 号 - 第17号，第175条，第177条，中小企 業等協同組合法施行規則第19条第 1 項第15号・第17号，第156条，第158条。

10）個人顧客情報の漏洩に関して保険会社に対する行政処分が行われたケースと しては, 生命保険会社の業務委託先の従業員がホストコンピュータにアクセス し, 約32,000件の個人顧客情報を社外に持ち出した結果，顧客名義のクレジッ トカードが不正利用された疑いがあるとして，金融庁が，平成22年 2 月 24 日付 で，保険業法第204条第 1 項に基づく業務改善命令㧍よび個人情報保護法第34 条第 1 項に基づく勧告を発した事例がある（金融庁ホームページ）。

また，金融庁が保険会社に対する検査において指摘した事例として，次のも のがある（内閣府ホームページ）。

・顧客情報統括管理部門は，個人デー夕の消去・廃棄の記録を行っておらず, 適切に消去等が行われたか把握していないほか，顧客データへのアクセス記 録を保管・分析していない。

・各部門長が, 部門内職員に対し，業務の実情に応じて，顧客情報の閲覧権限 を付与することとしているが, 権限付与の適切性を検証する態勢を構築して 
保険・共済実務における個人情報漏洩防止の近時の動向

ついて共済事業を実施する団体を監督する各省庁も，それぞれの監督指針に おいて，個人情報保護に関する監督の着眼点と行政処分の考え方を定めてい る $^{11)}$ 。

以下，本稿では，保険・共済の実務における個人情報の取扱いおよび漏洩 等の防止に関する近時の動向として，「反社会的勢力に関する個人情報の増 加」および「漏洩等防止の対策の強化」をとりあげる。

\section{3 反社会的勢力に関する個人情報の蓄積・管理・活用}

平成19年 6 月に犯罪対策閣僚会議において「企業が反社会的勢力による被 害を防止するための指針」の申合せが行われて以降，保険・共済事業者にお いても，各省庁の監督指針等の改正を受けて，基本方針の策定・公表，保 険 - 共済約款への暴力団排除条項の導入, 反社会的勢力対応部署の整備，警 察・暴力追放運動推進センター・弁護士等外部専門機関との連携等に取り組 んできており，その一環として，反社会的勢力に関する情報の蓄積・管理 · 活用をすすめてきている。

\section{（1）一般的な実務の流れ}

保険・共済契約およびそれ以外に事業者が締結する契約における反社会的 勢力の排除にかかる一般的な実務の流れ（全国暴力追放運動推進センターの 場合。平成27年 2 月現在）は，次のとおりである。

(1) 暴力追放運動推進センターからのデータ提供（反社会的勢力の関与し

いないため，業務上の必要がなく誤って権限を付与された職員が顧客情報を 閲覧している事例を看過している。

・委託先における顧客情報管理態勢が未整備であることを把握しているにもか かわらず，委託先に対して体制整備を求めていない。

11）農林水産省「共済事業向けの総合的な監督指針」II - 3 - 7, 厚生労働省 $「$ 共済事業向けの総合的な監督指針」II - 3 - 7, 中小企業庁「事業協同組合 等の共済事業向けの総合的な監督指針」 II $-3-7$ 。 
た事案にかかる警察発表をもとに，登録年月，都道府県名，事案名，掲 載紙，住所，漢字氏名，カナ氏名，性別，年齢，暴力団に扔ける地位を データベース化したものが提供される。)

(2) 契約先・給付先の反社会的勢力該当性を審査するためのデータベース 化および審査の実施

(3) 審査の結果, 反社会的勢力への該当性が疑われる者に関する暴力追放 運動推進センターへの人定照会および生年月日情報に基づく該当有無等 に関する暴力追放運動推進センターからの回答

(4) 暴力追放運動推進センターから「該当する」旨の回答があった者に関 する警察への照会および警察からの回答

(5)警察から「該当する」旨の回答があった者に関する対応方針（契約引 受の謝絶，暴力団排除条項に基づく解除等）の策定・実施

\section{（2）個人情報保護法との関係}

反社会的勢力に関する個人情報の取得 - 保有 ·利用と個人情報保護法の関 係については，上述の犯罪対策閣僚会議において申合せが行われた「企業が 反社会的勢力による被害を防止するための指針の解説」において，次のよう に整理されている。

ア．事業者が，反社会的勢力による被害防止という目的で利用するために 反社会的勢力の個人情報を直接取得すること，または他の事業者，暴力 追放運動推進センター等からデータベース化された反社会的勢力の個人 情報を取得することについては，個人情報保護法第 18 条第 4 項第 1 号 「本人又は第三者の生命, 身体又は財産その他の権利利益を害するおそ れがある場合」および同項第 2 号「事業者の正当な権利又は利益を害す るおそれがある場合」に該当し，本人への利用目的の通知または公表の 必要はない。

イ. 事業者が, 他の目的により取得した反社会的勢力の個人情報を被害防 止の目的で利用することは，個人情報保護法第 16 条第 3 項第 2 号「人の 
保険・共済実務における個人情報漏洩防止の近時の動向

生命, 身体又は財産の保護のために必要がある場合であって，本人の同 意を得ることが困難であるとき」に該当し，本人の同意を得る必要はな W。

ウ. 事業者が, データベース化した反社会的勢力の個人情報を, 被害防止 の目的で他の事業者, 暴力追放運動推進センター等の第三者に提供する ことは，個人情報保護法第23条第 1 項第 2 号「人の生命, 身体又は財産 の保護のために必要がある場合であって，本人の同意を得ることが困難 であるとき」に該当し，本人の同意を得る必要はない。

工．事業者が保有する反社会的勢力の個人情報については，個人情報保護 法施行令第 3 条第 2 項「存否が明らかになることにより，違法又は不当 な行為を助長し, 又は誘発するおそれがあるもの」に該当し, 個人情報 保護法第 2 条第 5 項により「保有個人データ」から除かれることから， 個人情報保護法第 24 条による公表等の義務はなく, 本人からの開示請求 に対し「保有個人データは存在しない」と回答し得る。

\section{(3) ガイドラインとの関係}

契約先となる個人が反社会的勢力に該当するか否かに関して, 上記(1)(1) の暴力追放運動推進センターから事業者に対して提供されるデータおよび(4) の警察への照会とそれに対する回答のなかで取り扱われるデータのなかには, その個人の犯罪歴に関するものが含まれている。これは金融庁のガイドライ ン第 6 条第 1 項の定める「人の生命，身体又は財産の保護のために必要があ る場合」に取得，利用および第三者提供を行い得る機微情報に該当し，同条 第 2 項により，事業者がその事由を冕脱した取得，利用および第三者提供を 行うことのないよう，特に慎重に取り扱うことが求められている ${ }^{12)}$ 。

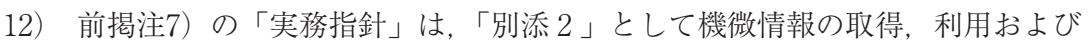
第三者利用がその目的を逸脱することを防ぐための措置をより詳細に定めてい る。 


\section{（4）実務上留意すべき事項}

反社会的勢力の排除にかかる上記の取組みが官民挙げて行われる以前に保 険・共済事業者が審査に用いていたデータベースは，道德的危険を有する者 からの請求履歴を中心とするものが一般的であり，この取組みをすすめるこ とにより，各事業者は，これまで取引経験のない者の，機微情報を含む属性 情報を大量に取得・保有・利用することとなった。

保険・共済事業者が取り扱う契約締結・給付の件数は澎大であり，関与す る拠点・職員の数も多い。したがって，犯罪歴を含む個人情報の漏洩等のリ スクを最小限とするために，上記(1)(2)において事業者が用いるデータベー スや書類について, 数多くの拠点でアクセスできるものについては機微情報 を含まず，反社会的勢力への該当（可能性）の有無のみを管理・表示するも のとし，犯罪歴を含む個人情報を取り扱う拠点・職員の範囲を，その取得・ 登録のために必要最小限のものに限る方向で体制・システム・手続を策定す ることが望ましい ${ }^{13)}$ 。

\section{4 個人情報の漏洩等の未然防止・再発防止の実務}

\section{（1） 内部不正による漏洩等の防止にかかる対策の強化}

平成26年に教育関係事業者において大量の個人情報の漏洩事案が発生した こと等を踏まえ, 同年 9 月30日に開催された個人情報保護関係省庁連絡会議 において「個人情報保護に関するガイドラインの改定について」の申合せが 行われたことを受けて，経済産業省は，同年12月12日にガイドラインの改正 を行った。内部不正による漏洩等の防止にかかる対策の強化に関して新たに 加えられた主な内容は，以下のとおりである。

(1) 第三者からの適正な取得の徹底

個人情報を適切に管理している提供元を選定し，その個人情報の取得方法

13）損害保険代理店におけるデータベースのあり方を指摘したものとして，第一 東京弁護士会民事介入暴力対策委員会編 ·保険業界の暴排条項対応 169 頁（金 融財政事情研究会, 2012)。 
保険・共済実務における個人情報漏洩防止の近時の動向

を確認したうえ, 適法に取得したことが確認できない個人情報の取得を自肃 する等，慎重に対応することが望ましい。

(2) 安全管理措置を講じるための組織体制の整備

個人データの取扱いを統括する部署の設置および社内の個人データの取扱 いを監督する「管理委員会」を設置することが望ましい。

監査実施体制として，個人情報保護対策および最新の技術動向を踏まえた 情報セキュリティ対策に十分な知見を有する者（外部の者を含む。）により 社内の対応を確認することが望ましい。

(3) 個人データの取扱いに関する規程等の記載事項

個人データを入力・利用・加工できる端末にスマートフォン, パソコン等 の記録機能を有する機器を接続することを制限し，媒体および機器の更新に 対応する旨定めることが望ましい。

(4) 個人データの盗難防止のための物理的安全管理措置

入退館 (室) の記録, 入退館（室）の際の記録機能を持つ媒体・機器の持 込み・持出しの禁止と検査の実施, カメラ撮影・作業立会い等による記録ま たはモニタリングといった手法を講じることが望ましい。

(5) 個人データへのアクセスにかかる技術的安全管理措置

アクセス権限を有する者の識別・認証を複数の手法の組合せにより行うこ とが望ましい。

個人データを格納するデータベースを構成要素とする情報システムの構築 にあたって，情報システム自体へのアクセス制御とは別に，データベースへ のアクセス制御を行うことが望ましい。

個人データへのアクセス・操作の成功 ·失敗の記録は, 情報システムを構 成する各システムの記録を組み合わせ，成功・失敗を全体として記録する手 法を講じることが望ましい。

システム管理者によっても個人データへのアクセスに関する記録の改竄・ 不正消去ができなくすることが望ましい。 
(6) 委託先の監督

委託先の選定にあたり，安全管理措置の実施について，委託先の社内体制， 規程等の確認, 必要に応じて実地検査等を行ったうえで適切に評価すること が望ましい。

委託先の個人データの取扱状況について，定期的に監査等を行うことによ り適切に評価することが望ましい。

委託先が再委託（再々委託を含む。）を行おうとする場合には，委託先か らの事前報告または承認を求める，委託先または自らが定期的に監査を実施 する等により，委託先が再委託先の監督を適切に果たし，再委託先が安全管 理措置を講じることを十分に確認することが望ましい。

個人データの委託にあたって，委託先において個人データを取り扱う者の 氏名・役職等および個人データが漏洩した場合の損害賠償に関する事項を契 約に盛り込むことが望ましい。

平成17～22年の「内部犯罪 ·内部不正行為」による個人情報漏洩の発生件 数は全体の $1 \%$ 程度であるのに対し，漏洩した個人情報の数は約 $25 \%$ にほ っているというデータがあり，こうした事案はひとたび発生すると大きな被 害・影響を生じる懸念がある ${ }^{14)}$ 。平成26年に発生した大量の個人情報漏洩事 案を受けて，社会的関心が高まるなか，各省庁はその対策に力を入れており， 保険・共済事業者における個人情報の漏洩等防止に関しても，当該事案の発 生以降，文書による行政指導に基づいて，端末機使用にかかる生体認証，デ 一夕の暗号化, 外部記憶媒体への出力制限, 職員の端末機使用履歴の点検, 委託先との契約内容の見直し等の取組みが行われているところであるが，今 後，上述の各項目と軌を一にする方向での対策の強化を求めるガイドライン の見直しが行われ，各事業者は，その内容に即した対応が求められることが 予想される。

14）情報処理推進機構・組織における内部不正防止ガイドライン（2.0版） 3 頁 (2014)。 
保険・共済実務における個人情報漏洩防止の近時の動向

\section{（2）意図されない漏洩等の防止にかかる対策}

平成25年度の個人情報漏洩の発生件数に関するデータによれば，金融業・ 保険業においては，「誤操作」，「管理ミス」および「紛失・置忘れ」の合計 で，全体の $97.3 \%$ 占めており ${ }^{15)}$ ，実務において発生している事案のほとん どが意図されないものであることを示している。

改めて指摘するまでもなく，保険・共済の実務においては，広範な部門・ 拠点において，多くの職員が日常的に大量の個人情報を取り扱っている。い わゆる「ヒューマンエラー」や盗難被害, 作業・配達の委託先での事故を含 めて，現実に漏洩等を完全に防ぐことはほぼ不可能である。このことは，各 拠点での漏洩等防止の取組みを日常的・継続的に行う必要性の背景であると 同時に，実際に漏洩等が生じた場合に適切な原因究明と再発防止に取り組む ことが必要であり，また，その経験の蓄積を必要な部門・拠点で広く活かし， 部門横断的な安全管理措置の充実につなげることが必要であることを意味し ている。

以下，近時の現場において発生頻度の高い漏洩等 ${ }^{16)}$ の原因や背景を検証し， 今後の漏洩等防止の取組みにおいて留意すべき点を考察する。

(1) 書類の不適切な取扱い

契約事務を所管する部門・拠点において発生頻度の高い事故として，他の 書類との混同による紛失・誤破重, 書類の保管・持出管理の不備による紛 失・誤破棄, 書類送付手順の不備による紛失・漏洩, 書類持参の際の取違

15） NPO 日本ネットワークセキュリテイ協会・2013年情報セキュリティインシ デントに関する調查報告書（第1.2版）18頁（2015）。この報告では，金融業・ 保険業について, 「個人情報の保管状態を再確認した結果, 紛失や誤廃棄が判 明したというケースが多い」と分析している。

16）本稿の内容は，筆者が実務において知り得た事案に基づいている。もとより, 漏洩等の発生状況は, 各事業者の実施する保険・共済の種類, 講じている安全 管理措置, これまでの経験等に応じて区々であり, 各事業者において発生した 漏洩等に関して公表される情報にも限界があることから，保険・共済にかかる 全ての実態を踏まえたものとはなっていない。 
え・置忘れによる漏洩等，書類の不適切な取扱いに起因するものが挙げられ る。

こうした事故を防ぐためには，書類の受付・回付・保管・持出し・送付 · 破棄にかかるルールを明確化し, 徹底することが必要であることはいうまで もないが, 日常的な事案の進捗管理をより綿密に行うことで担当者の処理遅 れによる個人保管の常態化を防ぐ，漏洩等が発生した後の類似案件調査や拠 点に対する監査・事務指導に伴う一斉点検を実施することによって不備状況 の把握と再発防止に拠点を挙げて集中的に取り組む, といった対策を講じる ことによって間接的にそのリスクを軽減することが可能である。

なお，書類の取扱いに関するルールにおいて「複数名によるチェック」を 行う旨定めるだけでは漏洩等を防ぎきれず，どういう職員がどこでどういう 視点で何をチェックするか, 通常のチェックができない場合はどうするか, といった点で具体的に設計された作業を徹底しないと，実体としてチェック が機能しない危険性があることに留意する必要がある ${ }^{17) 。 ~}$

(2) 給付先の登録誤り

損害保険・共済の分野にあっては，契約当初からの当事者・関係者以外の 者, 具体的には被害者, 修理工場, 医療機関, 質権者, 他の保険・共済事業 者等に対して給付が行われることが多い。そうした事案の処理にあたって， 給付先を誤って支払案内等の書類を送付するケースがあり，その大半が給付 先をシステム登録する作業の不備によるものである。

対策としては，複数の事案に関する情報が混在しないようなシステム面の 措置に加えて，担当者による入力から管理者による決裁に至る過程において， 原本確認を確実に行う具体的な手順をルール化する必要がある。

17）「担当者と管理者（決裁権者）の二重チェック」を未然防止策として揭げて いる拠点において，管理者のチェックが実体として機能しているか，それが機 能する条件・手法は何かについては, 特に慎重に吟味する必要があると考えら れる。 
保険・共済実務に㧍ける個人情報漏洩防止の近時の動向

(3) 業務用携带電話の紛失

職員が，担当する利用者の連絡先等を登録した業務用の携帯電話を紛失す るケースがある。携帯電話については，格納するデータを必要最小限とする こと，アプリケーションの追加を行わないこと，返却時にはデータを消去す ること等をルール化して使用させるほか, データの暗号化, 紛失後の使用停 止措置, 遠隔操作によるデー夕消去の機能により, 紛失や盗難被害を完全に 防ぐことができないことを前提とした対策が講じられており ${ }^{18)}$ ，そうしたル ールや対策を徹底することが必要である。

(4) 差押債権者からの照会に対する回答の際のマスク処理漏れ

解約返戻金を差し押さえた債権者からの照会に対して既存の帳票を提出し て回答しようとして，その際，開示する必要のない個人情報（電話番号，口 座番号）のマスク処理を怠ることによって漏洩等が生じるケースがある。

こうした照会への対応は, 他の拠点においても同様に発生し得る手続であ り，ある拠点で漏洩等が発生した場合には，個人情報保護の施策にかかる各 拠点の取組みを統括・指導すべき部門において，他の拠点で同様の事故が生 じるリスクの程度を検証し，必要があれば類似案件の発生状況の調査やその 未然防止・再発防止の措置を迅速に実施すべきである。

(5) 委託先の配達・配送にかかる過誤

郵便物の誤配達 ·未配達および帳票等の作成・梱包・配送の委託先の過誤 を原因とする漏洩等が発生している。委託する保険・共済事業者側の取組み でこれを完全に防ぐことは現実には困難であり，委託先の作業精度の向上に 期待せざるを得ない面はあるが，一般的な利用者宛ての郵便物とは異なり， 拠点間の帳票等の梱包・配送の過誤による事故については, 1 件で大量の個 人情報の漏洩につながるおそれがあることから, 委託先における原因究明と 再発防止に際しては，より高度な注意を払う必要がある ${ }^{19)} 。$

18）竹添英雄「生保会社と個人情報保護法」生命保険経営第 74 巻第 3 号 45 頁 (2006)。

19）より抜本的には, 物理的な紙の郵送・輸送自体の削減（ペーパーレス化）に 
以上，漏洩等の主な類型別に対策・留意点等を述べてきたが，個人情報を 取り扱う数多くの拠点においてこれらの対策を実効性のあるものとするため に考慮すべきと考えられる点は次のとおりである。

(1) 各拠点の業務プロセス・要員等を踏まえた具体的対策

個人情報を取り扱う部門の範囲が広く，漏洩等の対策を講ずべき拠点・職 員の数が多いことは既に述べたとおりである。各拠点の管理者・担当者の意 識・行動を現実に変えていくためには，それぞれの業務において取り扱う個 人情報の範囲 ${ }^{20)}$ を明確にしたうえで，業務プロセス，遵守すべきルール，要 員の数・スキル，先行事例（同一・類似の業務を行う拠点におけるものも含 む。漏洩等の前例だけでなく，有効な未然防止・再発防止策に関する情報の 共有も必要となる。）を踏まえ，各拠点が自らのリスクを具体的に分析し， 対策を適時に講じることが必要となる。そのためには，個人情報保護にかか る施策を統括する部門において, 自らが部門横断的・一元的に検討・実施す べき事項と，各部門・拠点において具体的・効率的に検討・実施するよう働 きかけるべき事項を適切に振り分け，立案・管理しなければならない。

(2) 職員の意識および作業精度を高める取組み

日々の業務において個人情報を取り扱う多くの担当者に適切な処理を促す ためには，「自分が個人情報の保護と利用者からの信頼確保の主体である」 という自覚 (当事者意識) と, 「1件 1 件の処理を適切に行わないと深刻な 事故につながりかねない」という緊張感を常に持ちながら業務にあたるよう 働きかける必要がある ${ }^{21)}$ 。

よって個人情報管理のコストと漏洩等のリスクを軽減することを検討する余地 があり, 近年では電子媒体の方が紙媒体よりも安全性が高いと評価されてもい るが，この点は，利用者とのコミュニケーションのあり方にも関わる論点であ り，慎重な検討を要すると考えられる。竹添・前掲注18）45頁。

20）個人情報保護法における個人情報の定義の曖昧さを指摘したものとして, 若 山高明「個人情報保護法の現状と課題一施行後の環境変化を踏まえた論点整 理一」生命保険経営第82巻第 6 号44頁 (2014)。

21） 漏洩等の内容によっては, 解決のために大きなコストを要する, 事業体全体 が社会的批判に晒され事業の継続が脅かされる，職員・責任者の身分も危うく 
保険・共済実務における個人情報漏洩防止の近時の動向

また, 経験の浅い職員や多忙がちな職員に対して適切な目配りと指導が行 えるよう，いわゆる「報告・連絡・相談」のしやすいコミュニケーション環 境を整えることも，漏洩等の発生・深刻化の抑止に効果があると考えられる。

さらに, 担当する業務の知識・スキルに関する指導・研修と, 個人情報保 護に関する指導・研修を分断せず，職員が両者を一体のものとして習得でき るよう配慮することも，個人情報保護に関する施策の実効性を高める結果に つながることが期待できる。

これらはいずれも各拠点の「職場（風土）作り」の取組みといえるもので あり, 適正な審査・給付や処理遅延の防止等他のコンプライアンス課題への 対応としても必要なものであると同時に，一過性の取組みで終わらせずに担 当者に繰り返し働きかけることが不可欠であることから, 各拠点の管理者に 対して,こうした取組みの実施と日頃の言動における率先垂範に向けた十分 な動機付けを行うことが求められる。

\section{5 おわりに}

2 で述べたように，個人情報保護にかかる法的・行政的規制により，保 険・共済事業者には部門横断的で多様な措置が求められている。 3 および 4 で概観した漏洩等防止の取組みはその一環に過ぎず，個人情報保護という課 題は，国民一般における権利意識の定着，個人情報保護法の改正動向 ${ }^{22)}$, 契 約締結・損害調査活動における携帯端末の活用の進展，大規模自然災害発生 後の加入先 ·加入内容に関する照会対応, 被相続人の加入先 ·加入内容に関 する照会対応，道德的危険を有すると疑われる者の加入先・加入内容に関す

なる等深刻な結果を招くことを職員にはっきりと認識させる必要があるが，上 司自身が職員に対して「脅し」にあたる方法でこれを行うことには，いわゆる 「パワーハラスメント」の問題があることから, 顧問弁護士等の第三者を通じ て強い指導を徹底させることも考慮しなければならない。

22）指紋認識データ・顔認識データの保護, いわゆる「ビッグデータ」の活用, 政府の行政組織から独立した第三者機関の設置といった制度改正に関して個人 情報保護法の改正が検討されていることについて，若山・前揭注20）47頁。 
る照会対応等, 様々な環境変化と対応すべき局面のなかにある。本稿の冒頭 で述べたように，高度な個人情報保護を求められる保険・共済事業において は，各事業者に対する，ひいては業界全体に対する社会的信頼の確保に向け て，従来にも増して高い問題意識と積極的な対応が求められているといえよ j。

（筆者は日本共済協会勤務） 